\title{
Can Placement Test Score Predict Success for a First-semester Community College Student in Their First Online Course?
}

\author{
Philip C. MacGregor ${ }^{1}$, Frances L. O’Reilly ${ }^{2}$, John Matt ${ }^{2}$ \\ ${ }^{1}$ Flathead Valley Community College, USA \\ ${ }^{2}$ The University of Montana - Missoula, USA \\ Correspondence: John Matt, The University of Montana - Missoula, USA.
}

Received: May 1, 2017

doi:10.11114/jets.v5i7.2456

Accepted: May 17, 2017 Online Published: June 1, 2017

URL: https://doi.org/10.11114/jets.v5i7.2456

\begin{abstract}
This study examined the following question: What is the relationship, if any, between COMPASS placement scores and the student success in the first online course during the students first semester? Discriminant function analysis was used to examine the relationship.

This study used existing data from new students, who took the COMPASS placement test, and were enrolled in an online course at community colleges in Idaho, Montana, Oregon, and Washington over 5 academic years from 2010 to 2015. Data collected from the participating community colleges included COMPASS placement test scores for reading, and writing, any of the four math sections, online course(s) attempted in the first semester, age, gender, course grade, and number of credits attempted during the student's first semester.

Statistically significant relationships were found between reading and writing COMPASS test scores and success in online humanities, natural science, and social science courses. For the math COMPASS scores, pre-algebra had a statistically significant relationship to success in online math courses and natural science courses. College algebra had a statistically significant relationship to success in an online natural science course. Prediction model results were just above and below $70 \%$ for each of the statistically significant relationships. The models included students who were predicted to be successful but were unsuccessful.
\end{abstract}

Keywords: community college, placement exams, completion, two-year colleges

\section{Introduction}

Attendance at community colleges has steadily increased over the years (Allen \& Seaman, 2014). Public community colleges have been using an open admissions policy that has allowed a student to quickly and easily enroll at the college and then register for classes (Vaughn, 2006). Community colleges have been actively reaching out to attract students who would not normally attend a university.

For the purpose of this study, community colleges include the public comprehensive colleges serving local communities in Idaho, Montana, Oregon, and Washington. These institutions offer transfer, technical, remedial, and community education courses, programs, and services (Cohen \& Brawer, 2008). Community colleges are open enrollment higher education institutions (Cohen \& Brawer, 2008). This means the student can fill out an application, submit high school transcripts, take a placement test and register for classes (Cohen \& Brawer, 2008). The placement test will determine if the student needs to take a remedial course. According to Cohen and Brawer (2008) many of these students are ill-prepared for the rigors of higher education. This is one factor in the low completion rates at community colleges.

This study was conducted in four states in the northwestern region of the United States consisting of Montana, Idaho, Oregon, and Washington. Montana has $25.3 \%$ of students in community colleges complete their programs in $150 \%$ of time, Idaho has $18.1 \%$, Washington has $28.8 \%$ and Oregon has 16\% (College Completion, 2016). In attempts to increase the number of community college graduates Idaho, Montana, Oregon, and Washington each have program retention and completion initiatives and performance-based funding.

Online courses are popular among students in higher education with 7.1 million students taking an online course in 2013 (Allen \& Seaman, 2014). There are more community colleges offering online courses than four-year colleges (Allen \& Seaman, 2014). Online courses offered have lower completion rates (69\%) than their face-to-face counterparts 
(75\%) (Allen \& Seaman, 2014; Moltz, 2011). Forty-one percent of chief academic officers say it is more difficult to retain online students, but online courses are also considered a critical part of the long-term strategy of colleges (Allen \& Seaman, 2014). Growth in online courses has slowed but still exceeds the growth in general for traditional courses in higher education (Allen \& Seaman, 2014).

Community college students in Idaho, Montana, Oregon, and Washington can take online courses beginning with the student's first semester. Initial advising of students as they begin the first semester at the community college is critical. Inventories are available that students can complete to gather information about their readiness to take an online course. Some students may not be ready to take an online course or their skill set might not be the right fit for online learning. Objective criteria are needed for the advisor to use as the student gets ready to register for classes.

\section{Purpose of the Research}

The purpose of this research was to determine if COMPASS placement test scores can predict student success in the student's first online course during the student's first semester at community college. The advisor can use the information from this study to determine if COMPASS placement test scores can be useful to place students in online courses. With proper placement there will be a greater likelihood that the student will succeed in an online course.

\section{Research Question}

For the purposes of this study, the following question was used to guide the research: What is the relationship, if any, between COMPASS placement scores and student success in the first online course during the student's first semester? The COMPASS Placement test is a computer-adaptive college placement test used to determine a student's skill level in mathematics, writing, and reading. It is used to determine proper math, writing, and reading course placement. This test is produced by ACT, Inc. ("ACT History," 2014).

\subsection{About Community Colleges}

According to the American Association of Community Colleges (AACC.), 7.3 million students enrolled in credit courses on a full- or part-time basis at community colleges across the country in the fall of 2014 ("2016 Fact Sheet," p. 2). Community colleges provide a wide range of services and program opportunities to these students, which include programs for transfer, workforce training, community education, contract training, and remedial courses.

Education beyond high school is essential in the $21^{\text {st }}$ century (Friedman, 2007). Research and a subsequent report from Fairweather (2006) found an unmistakable trend in the data he analyzed: "More education makes a difference" (p. 2). Individual benefits include higher wages earned throughout the individual's lifetime along with a better chance (prerequisite) to obtain a more stable position earning the worker an income closer to the middle class. States also benefit: "States with higher rates of college graduates are more prosperous than those states with lower rates" (Fairweather, 2006, p. 3).

Employment projections indicate $63 \%$ of all jobs will require a college education by 2018 (Carnevale, Smith, \& Strohl, 2010), and by 2020 that number will rise to 65\% (Carnevale, Smith, \& Strohl, 2013). This most recent report also indicated that the occupation clusters for those without any higher education will be largely limited to sales and office support, blue collar, and food and personal services. Information from the U.S. Bureau of Labor Statistics (2012) also indicated that the growth in occupations that require at least some post-secondary education will be greater than for those occupations that do not require post-secondary education through 2022. All of these statistics indicate that post-secondary education is vital in the $21^{\text {st }}$ century. Even of those jobs that only require a high school diploma or less, 91\% require on-the-job post-secondary training or an apprenticeship of at least 1 month to more than 1 year (U.S. Bureau of Labor Statistics, 2012).

The College Board agenda included a goal of 55\% of Americans holding a degree by 2025 (The College Board Advocacy, 2010). In order to accomplish this goal, the College Board developed recommendations, which included: (a) implementing research-based dropout prevention programs, (b) clarifying and simplifying the admissions process, (c) keeping college affordable, (d) increasing college completion rates dramatically, and (e) providing post-secondary opportunities as essential elements of adult education programs (The College Board Advocacy, 2010). The American community college is well-suited to tackle these challenges. The community college offers affordable tuition; open admission policies; flexible course schedules; convenient locations; responsiveness for students who are older, working, or need remedial classes; and integration with their communities, business/industry through partnerships (Cohen \& Brawer, 2008).

\subsection{About Online Courses}

Online courses are just one of the various forms of distance education. Over the last century, distance education has included correspondence courses; faculty traveling to distance sites; audio connections; videotapes and television; and one-way and two-way communications using audio, video, or both. 
In 1995, the Internet and the World Wide Web, together with graphical user interfaces, changed education in the form of online courses. Education was no longer bound by place or time (Reynolds, 2002). From 1995 to 1998, the percent of institutions offering online courses rose from $22 \%$ to $66 \%$, and the number of distance degree programs rose from 690 to 1,190 (Phillips, 1999). In fall 2013, over 5.5 million students were enrolled in distance education classes in the United States (NCES, 2016).

A study by Johnson and Benson (2003) revealed that $83 \%$ of colleges offer online programs to aid in reaching nontraditional students, $82 \%$ of colleges believe online programs reduce barriers for students, $79 \%$ believe online programs increase access to new audiences, and $74.8 \%$ of colleges believe online programs increase student access by making courses available at convenient locations. Additional research by Singh and Pan (2004) agrees with the findings of the Johnson and Benson (2003) study, stating that convenience and accessibility are advantages to web-based learning if properly administered.

The development of the personal computer, computer software, and Internet technology ushered in the advent of online courses. The flexibility they provide has increased the demand, causing the number of institutions offering online courses as well as the number of students participating in these courses to increase dramatically.

\section{Research Design}

This quantitative study was non-experimental and utilized data that were captured and recorded from the fall 2010 to the spring 2015 from students who enrolled at community colleges in Idaho, Montana, Oregon, and Washington. These students took the reading, writing, and math portions of the COMPASS placement test and took an online course in their first semester of college. The COMPASS test was chosen because it is the most commonly used placement test at community colleges in each of the four states. Data were collected from seven participating community colleges. These colleges were purposefully selected as colleges in the Northwest United States of Idaho, Montana, Oregon, and Washington that require the COMPASS Placement test for all new students and offer online courses. This study received prior approval from the University of Montana Institutional Review Board.

\subsection{Variables}

The dependent variable was successful or unsuccessful completion of the student's first online course or courses at Idaho, Montana, Oregon, and Washington community colleges. This was treated as a dichotomous categorical variable. The independent variable was the writing, reading, and one of the math either pre-algebra, algebra, college algebra, or trigonometry-COMPASS placement test scores for each student. These were treated as continuous interval level variables. The COMPASS placement test was required of each new student at the Idaho, Montana, Oregon, and Washington community colleges that participated in this study in order to place the student into the appropriate reading, writing, and math courses. Additional independent variables include the student demographic information of age, gender, and number of credits attempted in the student's first semester.

\subsection{Population and Sample}

The population for this research was new students who were accepted to one of the community colleges found in Idaho, Montana, Oregon, and Washington and who had taken the COMPASS placement test from fall 2010 to spring 2015 semester or quarter. The sample included data from new students in seven purposefully selected community colleges, who took the COMPASS placement test, and who were enrolled in an online course at participating community colleges in Idaho, Montana, Oregon, and Washington from fall 2010 to spring 2015. The results of this study can be generalized to community colleges in the northwest United States.

\subsection{Data Collection and Handling}

To obtain approval to use each institution's data, the researcher contacted the Vice President of Instruction or Dean of Instruction at each of the community colleges. The institutional researcher or appropriate research person at each institution extracted the data, eliminating any identifying data, including names, social security numbers, and student IDs. Seven electronic files of data were received and sorted rendering 6,117 student who met the inclusion criteria.

\subsection{Statistical Procedures}

Discriminant Function Analysis was used to determine the relationship between COMPASS placement scores and successful completion in the first online course during the student's first semester. Discriminant Function Analysis was used because it "explores the predictive ability of a set of independent variables, on one categorical dependent measure" (Steinberg, 2011, p. 104). Discriminant Function Analysis is similar to logistic regression in that both look at prediction, but Discriminant Function Analysis uses a dichotomous variable for the dependent variable (Steinberg, 2011). In this study, the dichotomous dependent variable was successful or non-successful completion of the student's first online course. 


\section{Research Findings}

Fourteen of the 27 combinations were statistically significant $(p<.05)$ and are listed in Table 1.

Table 1. Online Course Type and Compass Placement Tests That Have Statistical Significance

\begin{tabular}{lll}
\hline Course Type & COMPASS Placement Test & p-value \\
\hline Any Course & Reading, Writing, Pre-algebra & $<.001(3.1 \mathrm{E}-20)$ \\
Any Course & Reading Writing, Algebra & $<.001(1.7 \mathrm{E}-29)$ \\
Any Course & Reading, Writing, College Algebra & $<.001(6.6 \mathrm{E}-24)$ \\
Math Course & Pre-algebra & .002 \\
Writing Course & Writing & .003 \\
Humanities Course & Writing & .0004 \\
Natural Science Course & Writing & $<.001(2.9 \mathrm{E}-6)$ \\
Social Science Course & Writing & $<.001(3.8 \mathrm{E}-11)$ \\
Natural Science Course & Pre-algebra & .005 \\
Natural Science Course & College Algebra & .004 \\
Social Science Course & Pre-algebra & .001 \\
Humanities Course & Reading & $<.001(.0001)$ \\
Natural Science Course & Reading & .016 \\
Social Science Course & Reading & $<.001(2.3 \mathrm{E}-12)$ \\
\hline
\end{tabular}

The discriminate function analysis found $\mathrm{p}=3.173 \mathrm{E}-20$ for the reading, writing, and Pre-algebra scores; $\mathrm{p}=1.68 \mathrm{E}-29$ for the reading, writing, and algebra scores; and $\mathrm{p}=6.65 \mathrm{E}-24$ for the reading, writing, and college algebra scores. For these three variable combinations a statistically significant relationship exists between success in any online course in the students' first semester and COMPASS placement tests scores for reading, writing, and the math Pre-algebra, algebra, and college algebra. The Discriminant Function Analysis found $\mathrm{p}=.151$ for reading, writing, and trigonometry scores. Therefore, for these variables, there was no statistically significant relationship between success in any online course in the students' first semester and COMPASS placement test score for reading, writing, and trigonometry.

For each of the statistically significant variable combinations identified in Table 1, $n$ varies from $n=4,226$ students who attempted any online course and took the reading, writing, and college algebra COMPASS placement test down to $\mathrm{n}=276$ students who attempted an online natural science course and took the Pre-algebra COMPASS placement test. The combination of reading, writing, along with Pre-algebra, algebra, and college algebra with any online course each had a large $\mathrm{n}$. For the statistically significant variables, $\mathrm{F}$ indicates that these variables made a contribution to the prediction of the group membership.

It is apparent from the results that the ability of the student to read and write are important components for student success in any online course. Each time reading and writing were included as independent variables, the relationship to success was statistically significant.

Within the classification results for all of the models were a large number of successful students who were predicted to be successful. The classification results computed indicated just above or below $70 \%$ of students correctly classified for the statistically significant variables. The other $30 \%$ were not correctly classified.

For the 14 statistically significant combinations, the male student reading and math COMPASS placement scores were higher than the female student reading and math scores. The writing COMPASS placement scores were higher for the female student than for the male student. The female student COMPASS placement scores were statistically significant for 13 of the 14 overall combinations found in Table 1, but only nine of the 14 overall combinations were statistically significant for the male student and the COMPASS placement scores.

Classification results for female students reveal that the female students were predicted to be successful at a higher rate than male students with and without the age and credit variables. Classification results and the COMPASS placement scores do matter, more for the female than for the male. It cannot be determined based on the data used in this study whether there is gender bias in the COMPASS placement test scores. Female students were younger and took more credits than the male students. For both female and male students, the number of credits attempted was less than what a full-time student would take. The average age of female students was 25.41 while male students averaged 25.93 years of age. 


\subsection{COMPASS and Any Course}

There is one overarching null-hypothesis for this study. This null is that there is no relationship between COMPASS placement scores and the student's success in the first online course during the student's first semester at community colleges in Idaho, Montana, Oregon, and Washington. The following section presents findings of the Discriminant Function Analysis.

\subsection{Pre-algebra}

There were 3,009 students who took the Pre-algebra portion of the COMPASS placement test along with the reading and writing portions and took an online course in the first semester. There were 1,923 female and 1,086 male scores. The average age of all students was 27.794 and the average attempted number of credits was 10.5 during the students' first semester.

Table 2. Descriptive Statistics for Reading, Writing, and Pre-algebra in Any Online Course

\begin{tabular}{|c|c|c|c|c|c|c|}
\hline & \multicolumn{2}{|l|}{ Total } & \multicolumn{2}{|c|}{ Successful } & \multicolumn{2}{|c|}{ Unsuccessful } \\
\hline & M & SD & M & SD & M & SD \\
\hline \multicolumn{7}{|l|}{ Reading } \\
\hline Overall & 84.56 & 11.297 & 85.80 & 10.189 & 82.18 & 12.841 \\
\hline Female & 83.81 & 11.395 & 85.18 & 10.566 & 81.06 & 12.471 \\
\hline Male & 85.89 & 11.002 & 86.96 & 9.348 & 84.00 & 13.235 \\
\hline \multicolumn{7}{|l|}{ Writing } \\
\hline Overall & 71.89 & 25.532 & 74.74 & 23.844 & 66.40 & 27.694 \\
\hline Female & 73.20 & 25.145 & 76.30 & 23.359 & 66.94 & 27.379 \\
\hline Male & 69.57 & 26.052 & 71.85 & 24.473 & 65.54 & 28.211 \\
\hline \multicolumn{7}{|l|}{ Pre-algebra } \\
\hline Overall & 45.81 & 25.373 & 47.38 & 28.283 & 42.79 & 18.177 \\
\hline Female & 42.54 & 18.560 & 44.06 & 19.267 & 39.46 & 16.639 \\
\hline Male & 51.60 & 33.496 & 53.54 & 39.225 & 48.19 & 19.259 \\
\hline
\end{tabular}

Table 2 presents the descriptive statistics for the Reading, Writing, and Pre-algebra COMPASS placement test scores for taking any online course during the student's first semester. As Table 2 shows, the Overall mean was 84.56 for Reading, 71.89 for Writing, and 45.81 for Pre-algebra. The mean of the successful student was higher than the total mean and the mean of the unsuccessful student was lower than the total mean. The Overall standard deviations were 11.297 for Reading, 25.532 for Writing, and 25.373 for Pre-algebra. The standard deviations for the successful student were lower than the standard deviation for the unsuccessful student with the exception of Pre-algebra. In the case of Pre-algebra, the unsuccessful standard deviation was lower than the total standard deviation and the standard deviation for the successful student was higher than the total standard deviation. The means and standard deviations for Females and Males followed a similar trend. The means and standard deviations for each group did not change when including the Credit and Age variables.

Table 3. Independent Variable Correlations for Reading, Writing, and Prealgrebra and Any Course

\begin{tabular}{lccc}
\hline & Everyone & Female & Male \\
\hline Reading to Writing & .580 & .647 & .491 \\
Pre-algebra to Reading & .276 & .341 & .491 \\
Pre-algebra to Writing & .264 & .395 & .241
\end{tabular}

According to Pallant (2010), independent variable correlations above .8 or .9 are a cause for concern. High correlations between the independent variables can give erroneous and misleading results. The independent variable correlations in Table 3 were calculated with the correlation of Reading to Writing being .580 and the correlation of Pre-algebra to Reading and Pre-algebra to Writing at .276 and .264, respectively, all below .8. These correlations are all below .8; therefore, the independent variables are not related to each other. In addition, when calculated for Female and Male groups, the Reading to Writing correlation was .647 for Females and .491 for Males, while the correlations for Pre-algebra to Reading and to Writing for Females were .341 and .395, respectively, and .491 and .214 for Males, respectively. Again, these correlations are all below .8; therefore, the independent variables are not related to each other. 
Table 4. Model Prediction Results for Reading, Writing, and Pre-algebra in Any Online Course

\begin{tabular}{llll}
\hline & \multicolumn{2}{l}{ Predicted Group Membership } & \\
Actual Membership & Successful & Unsuccessful & Total \\
\hline Successful & & & \\
Overall & $1,883(95.1 \%)$ & $96(4.9 \%)$ & 1,979 \\
Female & $1,214(94.4 \%)$ & $72(5.6 \%)$ & 1,286 \\
Male & $672(97.0 \%)$ & $21(3.0 \%)$ & 693 \\
Age/Credit Female & $1,216(94.6 \%)$ & $70(5.4 \%)$ & 1,286 \\
Age/Credit Male & $663(95.7 \%)$ & $30(4.3 \%)$ & 693 \\
Unsuccessful & & & \\
Overall & $912(88.5 \%)$ & $118(11.5 \%)$ & 1,030 \\
Female & $554(87.0 \%)$ & $83(13.0 \%)$ & 637 \\
Male & $361(91.9 \%)$ & $32(8.1 \%)$ & 393 \\
Age/Credit Female & $562(88.2 \%)$ & $75(11.8 \%)$ & 637 \\
Age/Credit Male & $355(90.3 \%)$ & $38(9.7 \%)$ & 393 \\
\hline
\end{tabular}

Model prediction results in Table 4 reveal that $66.5 \%$ of the original grouped students were correctly classified, and $66.4 \%$ of the cross-validated grouped students were correctly classified. Female students were correctly classified $67.4 \%$ of the time while Males were correctly classified $64.8 \%$ of the time. Overall, 1,883 of the 1,979 students who were successful were predicted to be successful, and 118 of 1,030 students who were unsuccessful were predicted to be unsuccessful. The other 912 unsuccessful students were predicted to be successful. The number of Female and Male students predicted to be successful and were successful vary slightly from grouping to grouping. Males who were predicted to be successful and were successful were the highest percentage at $97.0 \%$. The unsuccessful Female students who were predicted to be unsuccessful had the highest percent in that grouping at $13.0 \%$.

\subsection{Algebra}

There were 4,226 students who had taken the algebra portion of the COMPASS placement test along with the reading and writing portions of the test and then took an online course in the first semester. There were 2,435 female and 1,791 male scores. The mean age of all students was 25.97 , and the mean number of credits attempted during the students' first semester was 10.31 .

Table 5. Descriptive Statistics for Reading, Writing, and Algebra in Any Online Course

\begin{tabular}{|c|c|c|c|c|c|c|}
\hline & \multicolumn{2}{|l|}{ Total } & \multicolumn{2}{|c|}{ Successful } & \multicolumn{2}{|c|}{ Unsuccessful } \\
\hline & M & $\mathrm{SD}$ & M & SD & M & SD \\
\hline \multicolumn{7}{|l|}{ Reading } \\
\hline Overall & 87.04 & 10.286 & 88.08 & 9.371 & 84.54 & 11.842 \\
\hline Female & 86.32 & 10.437 & 87.49 & 9.536 & 83.22 & 11.981 \\
\hline Male & 88.02 & 9.996 & 88.95 & 9.060 & 86.06 & 11.502 \\
\hline \multicolumn{7}{|l|}{ Writing } \\
\hline Overall & 78.02 & 23.245 & 80.43 & 21.404 & 72.22 & 26.280 \\
\hline Female & 79.06 & 22.611 & 81.72 & 20.564 & 72.02 & 26.032 \\
\hline Male & 76.61 & 24.015 & 78.57 & 22.447 & 72.46 & 26.587 \\
\hline \multicolumn{7}{|l|}{ Algebra } \\
\hline Overall & 32.01 & 17.152 & 32.71 & 17.644 & 30.32 & 15.789 \\
\hline Female & 31.42 & 16.325 & 32.42 & 16.915 & 28.77 & 14.326 \\
\hline Male & 32.82 & 18.191 & 33.14 & 18.650 & 32.13 & 17.174 \\
\hline
\end{tabular}

As Table 5 shows, the Overall mean was 87.04 for Reading, 78.02 for Writing, and 32.01 for Algebra. The means of the successful students were higher than the total mean and the means of the unsuccessful students were lower than the total means. The Overall standard deviations were 10.286 for Reading, 23.245 for Writing, and 17.152 Algebra. The standard deviations for the successful student were lower than the unsuccessful standard deviations with the exception of Algebra where the unsuccessful standard deviation was lower than for the successful student. The mean and standard deviations for Females and Males followed the trend of the Overall means and standard deviations. The means and standard deviations for each group did not change when including the Credit and Age variables. 
Table 6. Independent Variable Correlations for Reading, Writing, and Algebra and Any Course

\begin{tabular}{llll}
\hline & Everyone & Female & Male \\
\hline Reading to Writing & .578 & .634 & .522 \\
Algebra to Reading & .230 & .259 & .187 \\
Algebra to Writing & .304 & .304 & .308 \\
\hline
\end{tabular}

The independent variable correlations in Table 6 were calculated with the correlation of Reading to Writing calculated at .578 and the correlation of Algebra to Reading and Algebra to Writing at .230 and .304, respectively, all below .8. These correlations are all below .8; therefore, the independent variables are not related to each other. In addition, when the independent variable correlations were calculated for the Female and Male groups, the Reading to Writing correlation was .634 for Females and .522 for Males; Algebra to Reading and Algebra to Writing for Females was .259 and .304, respectively and .187 and .308 for Males. These correlations are all below .8; therefore, the independent variables are not related to each other.

Table 7. Model Prediction Results for Reading, Writing, and Algebra in Any Online Course

\begin{tabular}{|c|c|c|c|}
\hline \multirow[b]{2}{*}{ Actual Membership } & \multicolumn{2}{|c|}{ Predicted Group Membership } & \multirow[b]{2}{*}{ Total } \\
\hline & Successful & Unsuccessful & \\
\hline \multicolumn{4}{|l|}{ Successful } \\
\hline Overall & $2,895(97.0 \%)$ & $89(3.0 \%)$ & 2,984 \\
\hline Female & $1,708(96.7 \%)$ & $59(3.3 \%)$ & 1,767 \\
\hline Male & $1,194(98.1 \%)$ & $23(1.9 \%)$ & 1,217 \\
\hline Age/Credit Female & $1,708(96.7 \%)$ & $59(3.3 \%)$ & 1,767 \\
\hline Age/Credit Male & $1,186(97.5 \%)$ & $31(2.5 \%)$ & 1,217 \\
\hline \multicolumn{4}{|l|}{ Unsuccessful } \\
\hline Overall & $1,149(92.5 \%)$ & $93(7.5 \%)$ & 1,242 \\
\hline Female & $601(90.0 \%)$ & $67(10.0 \%)$ & 668 \\
\hline Male & $540(94.1 \%)$ & $34(5.9 \%)$ & 574 \\
\hline Age/Credit Female & $599(89.7 \%)$ & $69(10.3 \%)$ & 668 \\
\hline Age/Credit Male & $533(92.9 \%)$ & $41(7.1 \%)$ & 574 \\
\hline
\end{tabular}

Table 7 presents the Model Prediction Results for Reading, Writing, and Algebra COMPASS placement test scores. Classification results reveal that $70.7 \%$ of the original grouped students and cross-validated group students were correctly classified. Female students were correctly classified $73 \%$ of the time while Male students were correctly classified $68.5 \%$ of the time. There were 2,895 of the 2,984 students who were successful that were predicted to be successful, but only 93 of 1,242 students who were unsuccessful were predicted to be unsuccessful. The other 1,149 unsuccessful students were predicted to be successful. The number of Female and Male students predicted to be successful and who were successful vary slightly from grouping to grouping. The Male students who were predicted to be successful and comprised the highest percentage of Actual Successful Group Membership at 97.5\%. The unsuccessful Female students who were predicted to be unsuccessful with the Age and Credit variables had the highest percentage in that grouping at $10.3 \%$.

\subsection{College Algebra}

There were 2,858 students who had taken the college algebra portion of the COMPASS placement test along with the reading and writing portions and took an online course in their first semester. There were 1,617 female and 1,241 male scores. The mean age of all students was 25.57 , and the mean number of credits attempted during the students' first semester was 9.94 . 
Table 8. Descriptive Statistics for Reading, Writing, and College Algebra in Any Online Course

\begin{tabular}{|c|c|c|c|c|c|c|}
\hline & \multicolumn{2}{|l|}{ Total } & \multicolumn{2}{|c|}{ Successful } & \multicolumn{2}{|c|}{ Unsuccessful } \\
\hline & M & SD & M & SD & $\mathrm{M}$ & SD \\
\hline \multicolumn{7}{|l|}{ Reading } \\
\hline Overall & 87.29 & 10.301 & 88.31 & 9.432 & 84.55 & 11.917 \\
\hline Female & 86.23 & 10.546 & 87.37 & 9.781 & 83.02 & 11.901 \\
\hline Male & 88.66 & 9.809 & 89.57 & 8.788 & 86.36 & 11.696 \\
\hline \multicolumn{7}{|l|}{ Writing } \\
\hline Overall & 77.48 & 23.926 & 80.06 & 22.013 & 70.55 & 27.261 \\
\hline Female & 77.64 & 23.727 & 80.58 & 21.759 & 69.32 & 26.909 \\
\hline Male & 77.27 & 24.191 & 79.36 & 22.344 & 72.02 & 27.640 \\
\hline \multicolumn{7}{|l|}{ College } \\
\hline Overall & 30.85 & 16.371 & 31.94 & 16.958 & 27.91 & 14.283 \\
\hline Female & 29.97 & 15.771 & 31.11 & 16.210 & 26.73 & 13.977 \\
\hline Male & 32.00 & 17.060 & 33.06 & 17.864 & 29.32 & 14.535 \\
\hline
\end{tabular}

Table 8 shows that the Overall mean was 87.29 for Reading, 77.48 for Writing, and 30.85 for College Algebra. The mean of the successful student was higher than the total mean and the mean of the unsuccessful was lower than the total mean. The Overall standard deviations were 10.301 for Reading, 23.926 for Writing, and 16.371 for College Algebra. The standard deviations for the successful students were lower than the standard deviation for the unsuccessful students, with the exception of the College Algebra section. The unsuccessful standard deviation is lower than the total standard deviation and the successful standard deviation is higher than the total standard deviation. The means and standard deviations for Females and Males followed the trend of the Overall means and standard deviations. The means and standard deviations for each group did not change when including the Credit and Age variables.

Table 9. Independent Variable Correlations for Reading, Writing, and College Algebra and Any Course

\begin{tabular}{llll}
\hline & Everyone & Female & Male \\
\hline Reading to Writing & .609 & .646 & .573 \\
College Algebra to Reading & .267 & .286 & .230 \\
College Algebra to Writing & .311 & .316 & .307 \\
\hline
\end{tabular}

The independent variable correlations in Table 9 were calculated with the correlation of Reading to Writing being .609 and the correlation of College Algebra to Reading and to Writing at .267 and .311, respectively. When the independent variable correlations were calculated for the Female and Male groups, the Reading to Writing correlations were .646 for Females and .573 for Males, Algebra to Reading and to Writing for Females were .286 and .316, respectively, and .230 and .307 for Males, respectively. The independent variables are not related to each other. 
Table 10. Model Prediction Results for Reading, Writing, College Algebra in Any Online Course

\begin{tabular}{|c|c|c|c|}
\hline \multirow[b]{2}{*}{ Actual Membership } & \multicolumn{2}{|c|}{ Predicted Group Membership } & \multirow[b]{2}{*}{ Total } \\
\hline & Successful & Unsuccessful & \\
\hline \multicolumn{4}{|l|}{ Successful } \\
\hline Overall & $2,027(97.4 \%)$ & $55(2.6 \%)$ & 2,082 \\
\hline Female & $1,157(96.8 \%)$ & $38(3.2 \%)$ & 1,195 \\
\hline Male & $874(98.5 \%)$ & $13(1.5 \%)$ & 887 \\
\hline Age/Credit Female & $1,157(96.8 \%)$ & $38(3.2 \%)$ & 1,195 \\
\hline Age/Credit Male & $869(98.0 \%)$ & $18(2.0 \%)$ & 887 \\
\hline \multicolumn{4}{|l|}{ Unsuccessful } \\
\hline Overall & $722(93.0 \%)$ & $54(7.0 \%)$ & 776 \\
\hline Female & $380(90.0 \%)$ & $42(10.0 \%)$ & 422 \\
\hline Male & $334(94.4 \%)$ & $20(5.6 \%)$ & 354 \\
\hline Age/Credit Female & $380(90.0 \%)$ & $42(10.0 \%)$ & 422 \\
\hline Age/Credit Male & $330(93.2 \%)$ & $24(6.8 \%)$ & 354 \\
\hline
\end{tabular}

Table 10 presents the Model Prediction Results for Reading, Writing, and College Algebra COMPASS placement test scores. Classification results reveal that $72.8 \%$ of the original grouped students and $72.7 \%$ of the cross-validated group students were correctly classified. This is higher than the Algebra model. Female students were correctly classified $74.1 \%$ of the time while Male students were correctly classified $71.9 \%$ of the time. There were 2,027 of the 2,082 students who were successful that were predicted to be success and there were 54 of 776 students who were unsuccessful who were predicted to be unsuccessful. The other 722 unsuccessful students were predicted to be successful. The number of Female and Male students predicted to be successful and were successful vary from grouping to grouping. Male students who were predicted to be successful and were successful was the highest percentage at $98.5 \%$ while the unsuccessful Female students who were predicted to be unsuccessful with and without the Age and Credits was the highest unsuccessful prediction.

\subsection{Trigonometry}

There were 492 students who had taken the trigonometry portion of the COMPASS placement test along with the reading and writing portions and took an online course in their first semester. There were 259 female and 233 male scores. The mean age of all students was 21.30 and the mean number of credits attempted during the student's first semester was 9.60 .

Table 11. Descriptive Statistics for Reading, Writing, and Trigonometry in Any Online Course

\begin{tabular}{|c|c|c|c|c|c|c|}
\hline & \multicolumn{2}{|l|}{ Total } & \multicolumn{2}{|c|}{ Successful } & \multicolumn{2}{|c|}{ Unsuccessful } \\
\hline & M & SD & M & SD & M & SD \\
\hline \multicolumn{7}{|l|}{ Reading } \\
\hline Overall & 92.08 & 6.598 & 92.34 & 6.402 & 90.66 & 7.453 \\
\hline Female & 92.32 & 5.797 & 92.49 & 5.698 & 91.29 & 6.383 \\
\hline Male & 91.81 & 7.391 & 92.18 & 7.152 & 90.14 & 8.280 \\
\hline \multicolumn{7}{|l|}{ Writing } \\
\hline Overall & 90.68 & 13.101 & 91.08 & 12.931 & 88.56 & 13.878 \\
\hline Female & 91.79 & 11.470 & 92.34 & 11.346 & 88.26 & 11.801 \\
\hline Male & 89.45 & 14.630 & 89.60 & 14.462 & 88.81 & 15.536 \\
\hline \multicolumn{7}{|c|}{ Trigonometry } \\
\hline Overall & 39.86 & 16.601 & 40.08 & 16.678 & 38.71 & 16.237 \\
\hline Female & 38.33 & 14.984 & 38.73 & 14.716 & 35.80 & 16.604 \\
\hline Male & 41.57 & 18.112 & 41.66 & 18.635 & 41.14 & 15.709 \\
\hline
\end{tabular}

Table 11 shows that the Overall mean was 92.08 for Reading, 90.68 for Writing, and 39.86 for Trigonometry. The mean of the successful student was higher than the total mean and the mean of the unsuccessful student was lower than the total mean. The Overall standard deviations were 6.598 for Reading, 13.101 for Writing, and 16.601 for Trigonometry. The standard deviations for the successful student were lower than the total standard deviation. The unsuccessful 
standard deviations were higher than the total standard deviations with the exception of the Trigonometry section where the unsuccessful standard deviation was lower than the total standard deviation and the successful student was higher than the total standard deviation. The means and standard deviations for the Females and Males followed the trend of the Overall means and standard deviations.

Table 12. Independent Variable Correlations for Reading, Writing, and Trigonometry and Any Course

\begin{tabular}{llll}
\hline & Everyone & Female & Male \\
\hline Reading to Writing & .379 & .150 & .535 \\
Trigonometry to Reading & -.010 & .100 & -.083 \\
Trigonometry to Writing & .049 & .087 & .036 \\
\hline
\end{tabular}

The independent variable correlations in Table 12 were calculated with the correlation of Reading to Writing being .379, and the correlation of Trigonometry to Reading and Trigonometry to Writing at -.010 and .049, respectively. When the independent variable correlations were calculated for the Female and Male groups, the Reading to Writing correlation was .150 for Females and .535 for Males, Trigonometry to Reading and Trigonometry to Writing for Females was .100 and .087, respectively, and -.083 and .036 for Males, respectively. The variables are not related to each other.

Table 13. Model Prediction Results for Reading, Writing, and Trigonometry in Any Online Course

\begin{tabular}{llll}
\hline & \multicolumn{2}{l}{ Predicted Group Membership } & \\
\cline { 3 - 3 } Actual Membership & Successful & Unsuccessful & Total \\
\hline Successful & & & \\
Overall & & & \\
Female & $222(100 \%)$ & $0(0 \%)$ & 415 \\
Male & $191(100 \%)$ & $2(.9)$ & 224 \\
Age/Credit Female & $222(99.1 \%)$ & $2(.9)$ & 191 \\
Age/Credit Male & $191(100 \%)$ & $0(0 \%)$ & 224 \\
Unsuccessful & & & 191 \\
Overall & $77(100 \%)$ & $0(0 \%)$ & 77 \\
Female & $35(100 \%)$ & $0(0 \%)$ & 35 \\
Male & $42(100 \%)$ & $0(0 \%)$ & 42 \\
Age/Credit Female & $35(100 \%)$ & $0(0 \%)$ & 35 \\
Age/Credit Male & $42(100 \%)$ & $0(0 \%)$ & 42 \\
\hline
\end{tabular}

Table 13 presents the Model Prediction Results for Reading, Writing, and Trigonometry COMPASS placement test scores. Classification results reveal that $84.3 \%$ of the original grouped students and $83.9 \%$ of the cross-validated grouped students were correctly classified. Female students were correctly classified $85.7 \%$ of the time while Male students were correctly classified $82.0 \%$ of the time. In the Overall category, 415 students were predicted to be successful and were successful, but 77 students who were predicted to be successful were unsuccessful. The model did not predict any unsuccessful students who were actually unsuccessful. The students were either predicted to be successful and were successful, or the students were predicted to be successful and were unsuccessful. The only exceptions are two Female students with or without Age and Credits who were predicted to be unsuccessful but were actually successful.

The results of this research determined that there is a relationship between the COMPASS test scores for reading and writing and the student success in the first online course during the student's first semester. That this relationship exists is important for advisor to understand as they meet with the new student who is getting ready to register for an online class. In training advisors, it is important to understand the relationship between the COMPASS placement test score for reading and for writing and success in an online course. If the student is weak in reading and writing, remedial courses and additional support for courses need to be available for the student.

\section{Implications}

\subsection{Recommendations for Administrators}

Administrators should develop guidelines for advisors to use that reflect the COMPASS placement scores for reading and writing and also align curriculum to reflect the importance of reading and writing. Administrators also need to make resources available for students who register for a class with inadequate reading and writing ability to help these students succeed. 


\subsection{Recommendations for Advisors}

The advisor can use this study as a guide when advising students into online courses but it should not be used as the sole decision making tool. It is also important for the advisor to identify students who have poor reading and writing COMPASS placement scores. The students who needs help with reading and writing skills can be advised into developmental reading and writing courses and/or into face-to-face courses. Advisors need to also be aware of additional reading and writing support services that may be available and necessary for students who are struggling in their online courses. Even with the results of this study, the advisor must be aware that the COMPASS portion of the writing test is a multiple-choice test and a high score on the writing portion of the placement test may not be a good indicator of how well a student will do in a course that requires significant writing.

\subsection{Recommendations for Professors/Instructors}

A recommendation for professors is to make sure that a statement is included in the online course syllabus describing the amount of work in the course and the need for students to be able to read and write well in an online course. Additionally, if the professor notices poorly written assignments from a student, the professor can recommend that the student seek additional resources to help the student improve his or her writing and reading skills.

\subsection{Recommendation for Students}

Online courses can be difficult for students. Even with high COMPASS placement scores, students who should be successful in a course may end up not being successful. Students need to realize that various other factors affect performance in an online course other than placement test scores.

\section{References}

2016 Fact Sheet (2016). Retrieved from http://www.aacc.nche.edu/AboutCC/Documents/AACCFactSheetsR2.pdf

ACT history (2014). Retrieved from http://www.act.org/aboutact/history.html

Allen, I. E., \& Seaman, J. (2014, January). Grade change: Tracking online education in the United States. Retrieved from http://www.onlinelearningsurvey.com/reports/gradechange.pdf

American Association of Community Colleges. (n.d.). Students at community colleges. . Retrieved from http://www.aacc.nche.edu/AboutCC/Trends/Pages/

Carnevale, A. P., Smith, N., \& Strohl, J. (2010, June). Help wanted: Projections of jobs and education requirements through 2018. Retrieved from http://files.eric.ed.gov/fulltext/ED524310.pdf

Carnevale, A. P., Smith, N., \& Strohl, J. (2013, June). Recovery: Job growth and education requirements through 2020. Retrieved from https://cew.georgetown.edu/report/recovery-job-growth-and-education-requirements-through-2020/

Cohen, A. M., \& Brawer, F. B. (2008). The American community college ( $3^{\text {rd }}$ ed.). San Francisco: Jossey-Bass.

College Completion (2016). Retrieved September 20, 2016 from: http://collegecompletion.chronicle.com/

Fairweather, J. S. (with Hodges, J. P.) (2006, December). Higher education and the new economy. Retrieved from http://files.eric.ed.gov/fulltext /ED498601.pdf

Friedman, T. L. (2007). The world is flat: A brief history of the $21^{\text {st }}$ century. New York: Picador.

Johnson, S., Benson, A., Duncan, J., Shinkareva, O. G., Taylor, G. D., \& Treat, T. (2003, October). Distance learning in postsecondary career and technical education: A comparison of achievement in online vs. on-campus CTE courses. Retrieved from http://www.nrccte.org/sites/default/files/publication-files/distance_learning_post_cte.pdf

Moltz, D. (2011, May 18). Online ed trends at community colleges. Retrieved from www.insidehighered.com/news/2011/05/18/community_College_distance_education_enrollments_continues_to_gr oW

NCES (2016). U.S. Department of Education, National Center for Education Statistics. (2016). Digest of Education Statistics, 2014 (NCES 2016-006), Table 311.15.

Pallant, J. (2010). SPSS survival manual: A step by step guide to data analysis using SPSS (4 ${ }^{\text {th }}$ ed.). New York, NY:McGraw-Hill.

Phillips, G. W. (1999, December 17). The release of distance education at postsecondary institutions 1997-98. National $\begin{array}{lllll}\text { Center for } & \text { Education } & \text { Statistics. } & \text { Retrieved from }\end{array}$ http://nces.ed.gov/whatsnew/commissioner/remarks99/12_17_99.asp\#tech

Reynolds, K. A. (2002). Going the distance with distance learning: An analysis of motivational factors that influence 
e-learning course completion rates [Master's thesis]. Wright Patterson Air Force Base, OH: Air Force Institute of Technology. Retrieved from http://www.dtic.mil/dtic/tr/fulltext/u2/a400743.pdf

Singh, P., \& Pan, W. (2004). Online education: Lessons for administrators and instructors. College Student Journal, 38, 302-309.

Steinberg, W. (2011). Statistics alive ( $2^{\text {nd }}$ ed.). Thousand Oaks, CA: Sage. studentsatcommunitycolleges.aspx

The College Board Advocacy and Policy Center. (2010). The college completion agenda: state policy guide. Retrieved from http://www.ncsl.org/documents/educ/policyguide_062810sm.pdf

U. S. Bureau of Labor Statistics (2012). Education and Training outlook for occupations, 2012-2022. Retrieved from http://www.bls.gov/emp/ep_edtrain_outlook.pdf

Vaughan, G. B. (2006). The community college story. Washington D.C.: Community College Press.

\section{Copyrights}

Copyright for this article is retained by the author(s), with first publication rights granted to the journal.

This is an open-access article distributed under the terms and conditions of the Creative Commons Attribution license which permits unrestricted use, distribution, and reproduction in any medium, provided the original work is properly cited. 